\title{
Didaktika obecné didaktiky: Od deklarativní znalosti pojmů směrem k rozvoji didaktického myšlení
}

\author{
Karolina Duschinská, RadKa High
}

\begin{abstract}
Abstrakt: Obecná didaktika má klícové postaveni ve studijnich plánech navazujícího magisterského studia oborù učitelstvi všeobecnè vzdèlávacích predmètù a právem se od ni očekává položeni teoretických základů učitelské profese. Tato studie sleduje trí hlavni cíle: reflektovat vzdèlávaci potřeby budoucich učitelü, zpracovat tematickou analýzu nejpouživanèjšich vysokoškolských učebnic obecné didaktiky a analyzovat proces inovaci výuky obecné didaktiky ve svètle požadavkư na kvalitu vysokoškolské výuky. Osmiletý proces inovaci je ilustrován prüběžnými výsledky studentského hodnoceni výuky, dále jsou analyzovány základni aspekty výuky predmètu obecná didaktika: cíle predmétu, obsah, zkouška, činnosti ve výuce $i$ mimo výuku a využiváni príkladů z praxe. Zámèrem tèchto inovaci bylo postupně dojit k vyváženému modelu výuky obecné didaktiky založenému na propojováni teorii učeni a výsledkü empirického pedagogického výzkumu s porozuménim konkrétnim didaktickým situacim. Hlavním výsledkem této studie je šest požadavkü na výuku obecné didaktiky v učitelských studijnich programech.
\end{abstract}

Klíčová slova: obecná didaktika, didaktika obecné didaktiky, studium učitelství, rozvoj didaktického myšlení.

\section{ÚvoD}

Výzva monotematického čísla časopisu Pedagogika, formulovaná jako snaha „přispět $\mathrm{k}$ obecnější reflexi proměn $\mathrm{v}$ pojetí výuky pedagogiky ve vzdělávání učitelů základních a středních škol“, oslovila autorky uprostřed procesu inovování a systematického reflektování vývoje přednášek předmětu obecná didaktika. Smyslem těchto inovací je hledat způsoby zprostředkování didaktiky studentům učitelství tak, aby v co možná největší míř přispívala k rozvíjení jejich didaktického myšlení. ${ }^{1}$ To chá-

\footnotetext{
${ }^{1}$ Rozvoj didaktického myšlení je v tomto textu vymezen v individuální perspektivě. Slavík (2009) v obdobném významu používá termín rozvoj profesního myšlení, v jeho pojetí však kromě obecně didaktické roviny zahrnuje i didaktickou znalost obsahu: „Reflexi spojenou s interpretací učebních situací tedy můžeme pokládat za nejlepší způsob, jak rozvíjet profesní myšlení učitelů a jak ukazovat funkčnost didaktické teorie pro praxi. "Skalková (1996, 2007) naopak analyzuje rozvoj obecného didaktického myšlení v historické perspektivě.
} 
peme společně se Šturmou (1993, s. 57) jako procesy a činnosti, „které předcházejí, doprovázejí a následují jakékoliv učitelovo počínání ve smyslu didaktického aktu, jehož je žák prvořadým objektem, účastníkem a partnerem vzájemné interakce“.

Předložený text sleduje tři hlavní cíle: 1. reflektovat vzdělávací potřeby studentů učitelství, 2. přinést tematickou analýzu nejpoužívanějších vysokoškolských učebnic obecné didaktiky, 3. analyzovat vlastní inovace výuky obecné didaktiky ve světle požadavků na kvalitu vysokoškolské výuky. První cíl reaguje na snahy o modernizaci vzdělávání budoucích učitelů a potřebu propojování akademické př́ípravy $s$ požadavky praxe. Druhý cíl je chápán jako porozumění diskurzu obecné didaktiky v českém pedagogickém prostředí. Zde není zamýšleno analyzovat obecnou didaktiku jako pedagogickou disciplínu, ale jako profesní vědu pro učitele, která sleduje jak teoretické, tak praktické cíle, se zřetelem na učitele a žáka. Stěžejní je třetí cíl práce, který zachycuje a analyzuje proces hledání a částečně i nalézání vhodného obsahu, cílů a způsobu vedení přednášek jednoho z klíčových předmětů pedagogicko-psychologické prípravy. Studie shrnuje osm let úsilí o proměnu výuky obecné didaktiky ve studiu oborů učitelství všeobecně vzdělávacích předmětů pro 2. stupeň ZŠ a SŠ.

Metodologicky byly využity prvky akčního výzkumu, jehož hlavním cílem je komplexní analýza výuky za účelem zdokonalení vlastní vyučovací praxe. Jako data byly využity terénní zápisky autorek, studentská řešení průběžných úkolů v e-learningu, odpovědi studentů na otevřené otázky $\mathrm{v}$ závěrečném testu týkající se významnosti obsahu výuky a výsledky studentského hodnocení výuky. Ačkoli se opíráme o prvky akčního výzkumu, s pochopením pro čtenáre-výzkumníka připouštíme, že předložený text není ucelenou ani metodologicky čistou výzkumnou studií. Práce je založena na průběžné introspekci, je analýzou procesu proměny výuky $s$ výhledem do budoucna. Autorky zároveň reflektují skutečnost, že výzva k sepsání článku přišla uprostřed procesu změny, výsledky práce lze proto chápat jako průběžné.

$\mathrm{Na}$ didaktiku obecné didaktiky nahlížíme ze tří perspektiv: 1 . účel, $\mathrm{k}$ němuž výuka slouží, 2. obsah, tedy „co učit“, 3. proces, se kterým je spojena otázka ,jak vyučovat" (viz též tzv. konstitutivní aspekty obecné didaktiky; Janík, 2009, s. 654). Následující tři části studie sledují právě tyto tři perspektivy.

\section{1. ÚČEL OBECNÉ DIDAKTIKY}

VE STUDIU UČITELSTVÍ

Tato část vychází z reflexe širší společenské diskuse, týkající se vysokoškolské př́pravy budoucích učitelů. Vycházíme ze vzdělávacích potřeb, jak je formulují sami studenti, absolventi i např. budoucí kolegové a zaměstnavatelé. Akademická výuka obecné didaktiky je kritizována pro př́lišnou teoretičnost a - na rozdíl od oborových didaktik - pro minimální praktickou použitelnost získaných znalostí ve školní výuce. Vcelku pochopitelnou reakcí studentů učitelství i učitelů z praxe pak bývá odmítání teorie a důraz na prakticismus. 
Rostoucí zájem o ,jak“ bohužel bývá doprovázený ztrátou zájmu o „proč“, což se projevuje např. velkou popularitou publikací, které jsou sice užitečnými přehledy metodických návodů, avšak často postrádají teoretická zdůvodnění a ukotvení. Praktické ověřování různých výukových postupů je důležité, avšak bez nadhledu a porozumění prostřednictvím teoretické reflexe může didaktické myšlení budoucího učitele více brzdit než rozvíjet. Požadavek na propojování teorie a praxe ve výuce např̀. pregnantně shrnuje Janík v Pedagogické encyklopedii (2009; s. 651): „Didaktika jako profesní věda pro učitele sleduje také cíle praktické. ... Didaktická teorie může učiteli poskytnout oporu při řešení každodenních problémů ve výuce“. Dnes není problém najít řadu návodů a metodických doporučení týkajících se výuky. Problémem však může být se $\mathrm{v}$ informacích zorientovat, zařadit je do kontextu, porozumět, kdy a proč fungují a k jakým cílovým znalostem a dovednostem povedou žáky.

$S$ ohledem na výše uvedené aspekty formulujeme účel výuky obecné didaktiky v učitelských studijních programech. Obecná didaktika má rozvíjet didaktické myšlení budoucích učitelů. Má být zaměřená jak na deklarativní znalosti pojmů obecné didaktiky, tak na procedurální znalosti a dovednosti v oblasti plánování, realizace a evaluace výuky. Má nabízet dostatečně srozumitelný myšlenkový rámec pro porozumění procesům výuky a teoretické poznatky propojovat s konkrétními príklady z výukové praxe. Má kultivovat odborný diskurz a být otevřená směrem $\mathrm{k}$ praxi i směrem k oborovým didaktikám, což je předpokladem pro vzájemné dorozumění a odbornou komunikaci.

\section{Tematická analÝZa STUdijní LITERATURY K OBECNÉ DIDAKTICE}

Tato část práce je tematickou analýzou nejpoužívanějších vysokoškolských učebnic obecné didaktiky. Učebnice patří $\mathrm{k}$ informačním zdrojům jak pro vyučující na vysoké škole, tak pro studenty. Nejsou a ani nemají být zdrojem jediným, avšak do jisté míry reprezentují a ovlivňují obsah výuky. Reflexe vzdělávacích potřeb budoucích učitelů poukazuje na nutnost propojovat akademické teorie s príklady prakticky využitelnými ve školní výuce. Nabízí se otázka, jak se s tímto nárokem vypořádávají aktuální vysokoškolské učebnice obecné didaktiky dostupné $\mathrm{v}$ českém prostředí a jaké tematické obsahy zpracovávají. Analýza všech dostupných zdrojů není v tomto textu hlavní cílem, proto byly vybrány dvě základní učebnice, okrajově jsou zmíněny některé další české a zahraniční publikace.

\subsection{Obecná didaktika a Školní didaktika}

K tematickému porovnání jsme využily dvě základní učebnice, které se objevují v doporučené literatuře sylabů obecné didaktiky např́ic učitelskými fakultami v celé ČR.

Obecná didaktika (Skalková, 2007) je učebnicí obecné didaktiky, která je vhodná pro studenty učitelství i učitele z praxe. V úvodu každé kapitoly autorka uvádí obecné problémy, často kladené ve formě 
otázek. Následuje výklad teoretických znalostí a každá kapitola nebo subkapitola je zakončena úkoly nebo otázkami a seznamem rozšiřující studijní literatury.

Školni didaktika (Kalhous, Obst et al., 2009) je učební text koncipovaný pro studenty učitelství sekundárních škol. Na začátku každé kapitoly jsou kvalitně popsány cíle. Aktivita čtenářů je podpořena otázkami a úkoly, které jsou $\mathrm{k}$ dispozici na závěr před klíčovými slovy. U některých témat se také objevují kazuistické případy.

Oba literární zdroje jsme porovnaly tematicky, snažily jsme se zařadit obsah do podobných kategorií. Pro ilustraci jsou přidány i počty stran, přičemž nehledíme na kvantitu jako takovou (oba zdroje mají rozdílný počet stran), cílem bylo pouze grafické znázornění „důležitosti“ jednotlivých témat $\mathrm{v}$ rámci knihy $\mathrm{v}$ porovnání $\mathrm{s}$ ostatními. Následující graf (č. 1) shrnuje 16 tematických oblastí obsažených v učebnicích.

Co mají tyto dvě knihy společné a v čem se liší? Obě začínají vymezením didaktiky (v našem grafu označen jako didaktika), v prŕpadě Skalkové můžeme tuto část chápat jako vstup do vědního oboru, $\mathrm{v}$ prrípadě publikace Kalhouse, Obsta a kol.

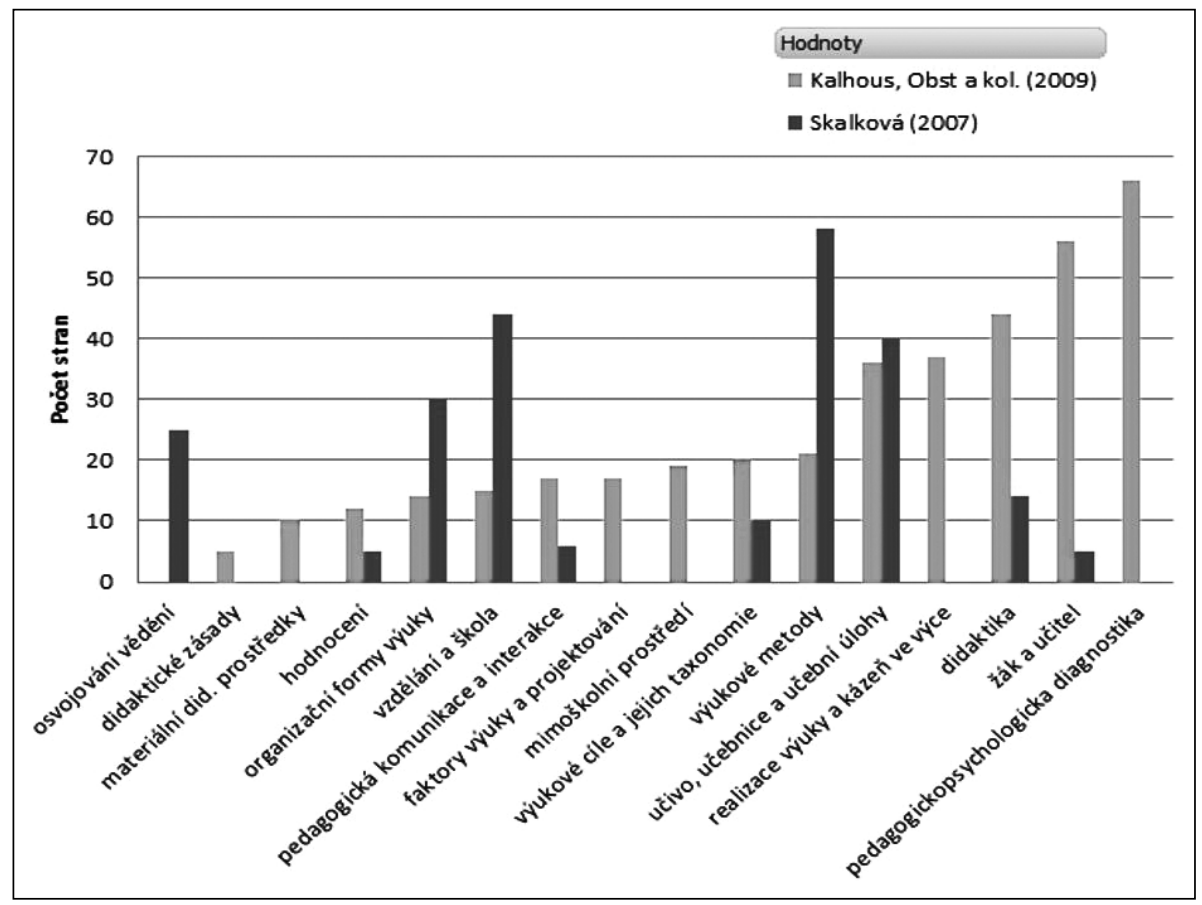

Graf 1. Tematická analýza učebnic 
jako polemiku nad tím, proč je didaktika důležitá. Popis systému vzdělávání je obsažen v tématu vzděláni a škola, prístupy jsou však jiné. Skalková popisuje fungování systému, Kalhous, Obst a kol. se soustředí na sekundární školu, její problémy a vývoj. Následuje téma učivo, učebnice a učebni úlohy. Skalková se zabývá především reformami vzdělávacích obsahů, inovačními koncepcemi, dále pojednává $\mathrm{o}$ uspořádání učiva $\mathrm{v}$ pedagogických dokumentech. Kalhous, Obst a kol. se také zmiňují o pedagogických dokumentech, ale přidávají popis struktury učiva, zprostředkující a vstrrícný prrístup $\mathrm{k}$ učivu. Toto uvedení do učiva je doprovázeno pojednáním o funkci učebnic.

Výchovné-vzdělávaci cíle považujeme za jedno z klíčových témat didaktiky. Skalková popisuje důležitost cílů, rozlišuje různé druhy cílů, přidává Bloomovu taxonomii cílů. Nenacházíme však ani jednu ukázku cíle, popis tedy zůstává $\mathrm{v}$ teoretické rovině. Kalhous, Obst a kol. taktéž zdůvodňují význam cílů pro učební činnosti žáků, popisují taxonomii kognitivních, afektivních a psychomotorických cílů, navíc popisují největší chyby při stanovování cílů a dávají př́klady cílů $\mathrm{z}$ několika disciplín. I přes snahu autorů o srozumitelnost a praktičnost považujeme za důležité ukázat cíle u každého stupně jednotlivých taxonomií. Pozitivní je, že autoři u každé kapitoly uvádějí několik cílů. Kriticky je nutné poznamenat, že poměrně často chybí naplnění požadavku kontrolovatelnosti cílů, o kterém je v této kapitole řeč.

Největší prostor je v publikaci Skalkové věnován vyučovacím metodám. Kapitola popisuje metody z hlediska historického vývoje, zabývá se klasifikací vyučovacích metod a jejich charakteristik. Autorka popsala mnoho metod, ale nedostává se $\mathrm{k}$ prímé aplikaci ve výuce. Stejným nedostatkem trpí i kniha Kalhouse, Obsta a kol. Organizačni formy výuky jsou dalším důležitým tématem. Ačkoli bez znalosti různých forem a možností aplikace ve výuce nelze kvalitně vyučovat, je z našeho pohledu v obou zdrojích malý prostor právě pro aplikaci. Pro ilustraci pojetí tohoto tématu uvádíme konkrétní př́klad hromadné frontální výuky, často využívané organizační formy především na vyšších stupních škol. Ve Skalkové je popsána na třech stranách, u Václavíka (in Kalhous, Obst a kol.) na třech a půl stranách. To neumožňuje hlubší porozumění tomu, jak efektivní frontální výuku naplánovat a vést. Oba zdroje popisují charakteristiky tohoto typu výuky, strukturu vyučovací hodiny a typologii vyučovacích hodin. Proti této struktuře nic nenamítáme, nicméně pro začínající pedagogy a/nebo studenty učitelství jsou tyto informace příliš teoretické a dle našeho názoru nepomohou při př́pravě kvalitní frontální výuky. Obdobné námitky máme i $\mathrm{k}$ dalším formám výuky v obou knihách.

Závěrem tematické analýzy můžeme souhlasit s Janíkem (2003), který uvádí, že především Skalková představuje systémové didaktické myšlení spjaté s didaktickým trojúhelníkem vyučování - učivo - učení. Kalhous, Obst a kol. se významnou měrou zaobírají i žákem, tedy aktivním participantem procesu výuky. Obě učebnice poskytují základní vhled do problematiky 
didaktiky. Pro studenty učitelství mohou představovat teoretický vstup do studované tematiky. Postrádáme však větší propojenost $s$ praxí. Kriticky musíme říci, že neznalý člověk získá prvotní povědomí, jak může při přípravě a vedení výuky postupovat, ale nedostane vodítko, proč, kdy a jakým způsobem různé metody do své výuky implementovat. Čtenář má $\mathrm{k}$ dispozici základní představení možností, ale je nadále ponechán $\mathrm{v}$ nejistotě ohledně jejich využití. Teoretický systém pojmů a vztahů tak zůstává izolován, nepropojuje se s porozuměním praktickým situacím. Samotné studium těchto publikací nevytvárí základ pro překlenování propasti mezi teorií a praxí v pregraduálním studiu a pravděpodobně ani v budoucím profesním životě studentů učitelství.

\subsection{Transdisciplinární didaktika}

Publikace Transdisciplinární didaktika: o učitelském sdileni znalostí a zvyšováni kvality výuky napríč obory (Slavík, Janík, Najvar \& Knecht, 2017) se snaží uchopit didaktiku novým způsobem, a to - jak název napovídá - transdidakticky. Záměr budovat didaktiku na poli průseč́ku oborových přístupů vzbuzuje velká očekávání. Monografie zmiňuje potenciál transdidaktiky být do jisté míry alternativou obecné didaktiky, obecní (i oboroví) didaktici patří $\mathrm{k}$ cílové skupině čtenářů. Autoři apelují na důležitost obsahu výuky, velký důraz kladou na didaktickou transformaci učiva. Publikace je založena na rozsáhlé empirické práci, která má vést $\mathrm{k}$ rozvíjení nejen oborových didaktik, ale také obecné didaktiky tím, že „slouží jako badatelské zázemí pro společně oborový diskurz".

Kniha je rozdělena do čtyř kapitol. První z nich se týká vztahu teorie a praxe, druhá pojednává o vztahu mezi kognitivní a hodnotovou stránkou didaktického výzkumu. Ve třetí kapitole je objasněna metodika $3 A$ (anotování - analyzování alterování výukových situací), poslední, čtvrtá kapitola pak přináší výsledky této metodiky na 44 didaktických kazuistikách $\mathrm{z}$ různých oborů. Analýza didaktických kazuistik směruje od oborových didaktik směrem ke společnému jádru, je originální a inspirativní. Vysoká intelektuální úroveň monografie však zároveň působí jako její omezení: porozumění poměrně hutnému a terminologicky náročnému jazyku vyžaduje zakotvení v dalších humanitních vědách. Ty nejpřínosnější myšlenky a výsledky rozsáhlého výzkumu tak dle našeho názoru může pochopit jen velmi znalý a motivovaný čtenár. Domníváme se, že monografie je $\mathrm{v}$ této podobě určena zejména pedagogickým výzkumníkům a teoretikům, pro studenty učitelství je obtižně srozumitelná.

\subsection{Další publikace}

Nejnovější publikace Obecná didaktika (Zormanová, 2014) je silná ve shromáždění a uspořádání velkého množství stávajících převážně českých zdrojů, včetně vlivné brněnské školy (Maňák, 2003). Sympatická je v našem prostředí výjimečná snaha o formulování vzdělávacích cílů kapitol, ty jsou však bohužel bud' př́liš obecné a ob- 
tížně kontrolovatelné, nebo jsou na nejnižší úrovni kognitivní náročnosti. Text je proložen př́klady z praxe, které ale nejsou analyzovány, a tak jejich potenciál zůstává nevyužitý. Za prŕnosnou považujeme kapitolu „Kurikulum a pedagogické dokumenty“, včetně prŕkladů.

Populární publikace Moderni didaktika: lexikon víukových a hodnoticich metod (Čapek, 2015) dle našeho názoru není didaktikou. Nerozporujeme ani tak absenci didaktických teorií či otevřenou kritiku akademické přípravy budoucích učitelů. Problémem je dle našeho názoru absence nadhledu, cílevědomosti či jakéhokoli vodítka pro rozhodování o výuce, což v kontextu žádoucího pojetí didaktiky nelze považovat za moderní ani účelné. Jedná se snad o užitečnou sbírku či lexikon, jehož podtitul měl zůstat hlavním názvem publikace.

Některé další publikace na českém trhu obsahují podnětné přístupy, které kombinují praktickou využitelnost a srozumitelnost $s$ požadavky na solidní teoretické a výzkumné ukotvení. Kniha $O d$ vzdèlávaciho programu k vyučvaci hodinè (Pasch, 2005) je výborným vhledem do plánování výuky, s řadou vysvětlujících praktických př́kladů a jejich důkladnou analýzou. Bohužel, je v některých částech již poněkud zastaralá a vázaná na zahraniční kontext. Moderni vyučováni (Petty, 2013) česky vyšlo již v šestém ${ }^{2}$, přepracovaném vydání, což dokládá oblíbenost této publikace. ${ }^{3}$
Autorem je britský respektovaný pedagog a vzdělavatel učitelů, publikace je primárně orientovaná na potřeby praxe, zároveň stručně objasňuje teoretická a výzkumná východiska. Pro účely komplexního rozvoje didaktického myšlení budoucích učitelů je málo systematická, jako vstupní publikace do porozumění základům vyučování a učení ale zatím nemá na našem trhu konkurenci.

\subsection{Závěr analýzy studijní literatury}

Při pohledu na český trh $s$ odbornými publikacemi nemají vyučující obecné didaktiky ani studenti učitelství jednoduchou situaci. Nejpoužívanější učebnice obecné didaktiky nejsou dostatečně vstřícné ke svému čtenáři. Možným důvodem mohou být i kulturní zvyklosti v psaní odborných textů. Srozumitelnost a vstřícnost odborné literatury směrem $\mathrm{k}$ př́ijemci výstižně charakterizuje Chamoniklasová (2005, s. 157): „Anglofonní autoři se snaží podávat myšlenky snadno pochopitelnou formou. ... Anglické texty se orientují především na čtenáře. České odborné texty mají díky volbě lexikálních a gramatických prostředků intelektuálnější charakter než texty anglické, ale jsou často méně logicky strukturovány. Česky psané texty jsou orientovány především na téma. “ Autorky nepředpokládají, že studující budou využívat jen jediný informační zdroj;

\footnotetext{
${ }^{2}$ Zajímavé je, že v Británii vyšlo v roce 2014 teprve páté vydání. Otázkou je, zda vyšší počet českých vydání je způsoben malým nákladem, nebo nedostatkem jiné nabídky.

${ }^{3}$ Spoluautorka tohoto článku s vděčností vzpomíná na první české vydání (1996), které pravidelně studovala jako začínající učitelka na gymnáziu.
} 
vyhledávání a využívání řady aktuálních domácích i zahraničních zdrojů je samozřejmým požadavkem vyučování i studia na vysoké škole. Domnívají se však, že moderní učebnice obecné didaktiky, která by dobře a komplexně naplňovala vzdělávací potřeby budoucích učitelů, $\mathrm{v}$ českém vzdělávání učitelů citelně chybí. Taková publikace by měla být ke svým čtenářům dostatečně vstřícná a zároveň solidně teoreticky zakotvená.

\section{VÝVOJ VÝUKY OBECNÉ DIDAKTIKY}

V textu uvedeme jednotlivé etapy vývoje přednášek předmětu Obecná didaktika, které jedna ze spoluautorek vyučovala pro prezenční i kombinovanou formu studia od roku 2011. Etapy jsou řazeny od nejstarší po nejnovější, reflexe výuky vychází z terénních poznámek a introspekce, v každé etapě jsou ilustrativně kurzivou doplněny informace ze studentského hodnocení výuky, ${ }^{4} \mathrm{kde}$ se zaměřujeme pouze na odpovědi na položku „ $\mathrm{V}$ tomto provedení vnímám předmět jako prŕnosný pro svůj rozvoj“.

\subsection{Etapy vývoje}

\section{Následování autority}

Na počátku př́ípravy na vyučování byla vcelku logická práce s analýzou stávajících klíčových publikací (srovnej s předchozí kapitolou) a navázání na tradiční způsob výuky předmětu. Spoluautorka měla pětiletou zkušenost $s$ vyučováním na střední škole, proto vedle tradičních didaktických zásad a trojúhelníků ilustrativně - a nutno přiznat, že zpočátku spíše intuitivně - zařazovala i vlastní pedagogické zkušenosti. Vliv práce kolegů (Starý, 2006) i kontakty se zahraničím otevřely zájem o edukaci založenou na důkazech, jejíž oprávněnost byla potvrzena plenárním vystoupením prof. Mareše na konferenci ČAPV a následným článkem (Mareš, 2009).

Studentské hodnocení: průměr 3,00, modusem byly hodnoty 2 a 5 , ilustrativní výroky: "Přiznám se, že můj nejsilnějši dojem z tohoto predmètu byl, musim se nadrtit nazpamét', jak správnè učit, aby se dèti $v$ hodinách nemusely drtit memorovánim... Jako u vétšiny predmètů univerzitniho základu mi $i$ u obecné didaktiky uniká jeji smysl. ... Z druhé strany oceñuji profesionalitu, se kterou byly prednášky vedeny, to, že čerpá i ze zahraničnich zdrojů a drži krok se současným vývojem védy."

Hodnocení bylo rozporuplné a výsledky nemohly být důvodem ke spokojenosti.

\section{Zařazování zahraničních zdrojů}

$\mathrm{V}$ této etapě se otevírá prostor pro hledání argumentů, posilování role za-

\footnotetext{
$\overline{{ }^{4}}$ Jde o anonymní anketu, které se u velkých předmětů zúčastňuje obvykle 10-20\% studentů, neposkytuje proto reprezentativní výsledky. Škála je pětistupňová s klasifikací jako ve škole, tj. $1=$ nejlepší, $5=$ nejhorší. Jedná se často o jediný způsob hodnocení kvality vyučování, negativní výsledky jsou řešeny na pohovoru s vedoucím pracoviště, výjimečně následují i další kroky. Výsledky hodnocení jsou zpětnou vazbou, která obsahuje jak irelevantní, tak podnětné komentáre; vyučující má pak úlohu je od sebe odlišit.
} 
hraničních autorit, zapojování kritického myšlení. Př́klad: špatná pověst frontální transmisivní výuky je mýtem, nebot výzkumy jednoznačně prokazují její efektivitu, pokud je dobře vedena. To je v rozporu $s$ řadou tvrzení nejen ve veřejném pedagogickém prostoru, ale i v některých učebnicích obecné didaktiky; zde se nabízí možnost ukázky odborné argumentace. Uplatňuje se mnoho dalších inspirativních materiálů v angličtině, nově i představení koncepce modelů výuky (Estes, Mintz \& Gunter, 2010).

Studentské hodnocení: 2,38, modus 2, ilustrativní výroky: „Dle mého názoru prìlis teoretizováni, neustálé grafy a obrázky nepripravi studenty a ucitelskou profesi." „Diskuse se studenty byla velmi dobre vedena a byla k vèci."

Hodnocení opakovaně obsahovalo i kritiku využívání materiálů $\mathrm{v}$ angličtině, což od generace studentů prezenční formy studia spoluautorku překvapilo.

\section{Zařazování poznatků}

\section{z kognitivní psychologie}

Modely výuky (models of instruction, Estes et al., 2010) lze důkladně pochopit až po porozumění základům teorií učení. K informačním zdrojům přibývá reprezentativní publikace psychologie učení (Slavin, 2012), k tématům Teoretické základy vyučování a učení. Začínají se uplatňovat ilustrativní ukázky výukových situací na videozáznamech.

Studentské hodnocení: 3,04, modus 2, ilustrativní výroky: „Prednášky jsou pečlivě pripravené $i$ zajimavé, presto si vyučujici moc neziskává své posluchače, což je velká škoda. “- „Přednáška mi prijde velmi prínosná a oceñuji zapojeni aktuálnich informaci, videi a grafú do prednásky. “- „Zajimavé je, že predmèt právě pojednává o didaktice, ale sám vše, co obsahuje, popirá. Navrhuji zrušit tento predmèt. "

Hodnocení v tomto semestru bylo zklamáním, a to i při zvážení skutečnosti, že třetina studentských komentářu obsahovala téměř totožné negativní formulace, včetně návrhů na zrušení předmětu. Zklamání bylo o to větší, že př́ípravu provázelo dosud asi největší úsilí. Výsledky hodnocení přispěly ke změně, i když nebyly zdaleka jediným impulzem.

\section{Propojování obsahu a formy}

Do centra koncepce výuky se dostávají další praktické př́klady a interaktivita, které souvisí s požadavkem na rozvoj didaktického myšlení a procedurálních znalostí. Velká pozornost je věnována jak aktivizaci studentů, tak zachování teoretické náročnosti. Připravuje se důsledné propojování obsahu a formy, např. konstruktivistickou výuku lze demonstrovat modelovou lekcí $s$ induktivně vedeným budováním významu nového učiva, pravidla kvalitního výkladu dobře vedeným výkladem. Obě spoluautorky začínají v tandemu vyučovat kurzy vysokoškolské didaktiky pro akademické pracovníky, což dále ovlivňuje i pojetí výuky obecné didaktiky.

$\mathrm{K}$ této fázi přiřadíme čtyři semestry. Studentské hodnocení postupně, průměr (modus): 2,82 (2); 1,88 (1); 2,66 (1); 1,64 (1). Výroky: „Nechápu, proč nejsou propojené oborové didaktiky s obecnou didaktikou. " - „Poprvé za pèt let studia na fakultè jsem 
mél pocit, že v rámci univerzitního základu má prednáška smysl a má mi co dát a mám divod na ni chodit. Velmi oceñuji zavedení dobrovolných domácich úkolì, které človè$k a$ zároven nutily premýslet $v$ souvislostech predmètu a také pripravovaly na budoucí zkoušku a predevšim praxi.“ - „... prìstup vyučujici $k$ predmètu, který pojimala nejen teoreticky, ale také hodně prakticky." "Předmèt byl prínosný, avšak v hodinách se mohlo lépe pracovat s efektivnimi výukovými strategiemi. V aule plné lidí stavèt část výuky na aktivitách vhodných spišs pro seminár püsobi misty směšnè a jako ztráta času. “- „Práce s takovým množstvim studentü, kteři chodili na prednášky, neni snadná, a i presto se vyučujicim darilo zařadit aktivity, do nichž byli zapojeni témér všichni studenti. "

Zdá se, že aktivizující formy výuky nemusí vyhovovat úplně všem, ale jsou jednou z cest, jak výuku zkvalitnit a dát obecné didaktice smysl.

\section{Týmové vyučování}

Obě spoluautorky pravidelně vyučují $\mathrm{v}$ tandemu didaktiku vysokoškolské výuky, jednu pedagogickou situaci tak mohou komentovat jak z pedagogické, tak z psychologické perspektivy. To je kladně hodnoceno akademickými pracovníky, současně to rozšiřuje obzory oběma vyučujícím. V rámci přednášek obecné didaktiky spočívá týmová výuka nikoli v tandemu při vyučování, ale v rozdělení témat při přípravě a v obohacení obou pohledů. Tematika psychologických základů učení je nyní vyučována psycholožkou, která teorie učení nezná pouze $\mathrm{z}$ účelového samostudia, ale má vhled do souvislostí, a zároveň se klade důraz na uvádění příkladů ze školního života žáků. Důležitost úzké spolupráce pedagogů a psychologů se mimo jiné promítla i do plenárního vystoupení prof. Průchy na konferenci ČAPV (Průcha, 2018).

Studentské hodnocení 1,41 (1). Výroky: „Výborné prédnášky, bylo príjemné na nè chodit Bylo to všechno trochu fofrem, ale na to už jsme si na univerzitě asi v̌̌ichni zvykli - času málo, látky hodnè."

Následujícího sdělení si velmi vážíme, dokládá smysluplnost našeho úsilí: "Tento predmét je vhodný také pro učitele, kterí maji za sebou $i$ mnoho let praxe. Velice mne oslovila otázka cílu, které učiteli mohou velmi pomoci prí zaméreni práce jeho žákù. Skutečně pro praxi prínosná je i znalost efektivnich strategii. Osobně postupně zařazuji do vlastni výuky jednotlivé informace. Žáci se tak $v$ hodinách vice zapojují, jsou motivovani, orientuji se v probirané látce, ochotně spolupracuji a cití se $v$ hodinách príjemné. Nevýhodou je však zpomaleni postupu v probirané látce, vyváżeno je to hlubšim porozumèním a skutečným praktickým využitím obsahu výuky."

Pro tuto fázi máme $\mathrm{k}$ dispozici i další hodnocení kurzu. V poslední verzi testů byla přidána otázka týkající se zajímavosti přednášek, jejíž přesné znění bylo: „Jaké téma $\mathrm{z}$ obecné didaktiky a školní pedagogiky vás nejvíce zaujalo? Uved'te důvody.“

Informace jsou získané ze 148 dostupných testů. Studenti nejvíce oceňovali témata týkající se efektivnich výukových strategii (47), hodnoceni (34), kurikulárnich dokumentu் (22), taxonomie cílu (21), metakognice (21), socio-konstruktivisticky orientovaných modeli̊ výuky (18), informačnè 
procesni a kognitivni teorie učeni (13), realizace výuky (11), druhư učení (10). Za důležité považujeme zdůvodnění významu dialogické výuky: „... uvědomèni si, že nejde o to, co dèlá učitel, ale co dělaji žáci“.

\section{Plány: systematický rozvoj didak- tického myšlení}

Jednotlivé komponenty výuky obecné didaktiky fungují nyní poměrně dobře. Do budoucna plánujeme rozvíjet společný analytický rámec, který se ještě důsledněji zaměři na potřeby budoucího učitele i na kultivaci didaktického myšlení a zároveň přispěje $\mathrm{k}$ větší uspořádanost učiva. Inspirativním zdrojem pro tuto budoucí etapu je publikace The Strategic Teacher: Selecting the right research-based strategy for every lesson (Silver, Strong \& Perini, 2007).

\subsection{Proměna klíčových aspektů výuky obecné didaktiky}

$\mathrm{V}$ této části shrnujeme přehled klíčových aspektů výuky obecné didaktiky, které prošly během osmi let zásadní proměnou. Charakterizujeme nynější stav, který lze chápat jako průběžnou vývojovou fázi.

\section{Cíle výuky}

Cíle výuky chápeme jako stěžejní prvek, u kterého začínají (a končí) smysluplné inovace výuky (Biggs \& Tang, 2011). V hierarchii výukových cílů rozlišujeme cíle předmětu a cíle jednotlivých lekcíl /přednášek. Předpokladem pro rozvoj didaktického myšlení je zvládnutí myšlenkových operací v oblasti učiva didaktiky na úrovni porozumění a analýzy, zahrnutí jak deklarativních, tak procedurálních znalostí. Uvádíme zde ukázku formulace výukových cílů z přednášky na téma Výchovně-vzdělávací cíle: „Na konci dnešni prednásky: 1. Rozpoznáte vhodně formulovaný výukový cíl. 2. Vysvètlite a na príkladech doložite vyzznam kognitivnich, afektivnich a senzomotorických cilì ve výuce. 3. Porovnáte tři výnkové cíle $z$ hlediska kognitivní náročnosti. 4. Posoudite, zda modelový plán vyučovaci hodiny splňuje požadavek na soulad cilü, cinností v hodině a hodnoceni výsledkư učeni žákù, prípadně navrhnète vhodnèjši alternativu“. Cíl předmětu Obecná didaktika je nyní formulován takto: „Studujicí charakterizuje a uvede do souvislosti základni didaktické pojmy v kontextu výnky. Analyzuje modelové výnkové situace soporou o odbornou argumentaci, na príkladech vysvètli postup plánováni, realizace a evaluace výuky. "

\section{Obsah}

Sylabus předmětu $\mathrm{v}$ současné době zahrnuje tato témata: Obecná didaktika jako vědní disciplína, různá pojetí jejího místa $\mathrm{v}$ pedagogických vědách $\mathrm{a} \mathrm{v}$ praxi učitelské profese $\mathrm{v}$ historickém a mezinárodním kontextu. Didaktický výzkum, informační zdroje. Teoretické základy vyučování a učení, paradigmata učení a jejich didaktické implikace. Determinanty výuky. Výchovně-vzdělávací cíle a jejich klíčové postavení v procesu plánování a realizace výuky. Vztahy mezi cíli, hodnocením výsledků učení a činnostmi žáků. Cíle a prostředky pedagogické diagnostiky, hodnocení výsledků učení žáků, formativní hodnocení. Výsledky českých 
žáků v mezinárodním srovnání. Modely výuky, efektivní výukové strategie, metody vyučování, organizační formy výuky. Transmisivní vyučování, podmínky pro jeho efektivní realizaci, výklad a frontální interaktivní výuka. Podpora metakognitivních strategií. Konstruktivistické vyučování a podmínky pro jeho efektivní realizaci, badatelsky orientovaná výuka. Sociálně orientované modely výuky, efektivně vedené kooperativní vyučování. Potřeby žáků ve výuce, didaktické prostředky individualizace a personalizace výuky. Základy teorie kurikula. Analýza systému a struktury kurikulárních dokumentů v ČR, fáze implementace kurikula. Procesy plánování a evaluace výuky.

\section{Atest}

Podmínky zakončení předmětu musí být naplánovány $\mathrm{v}$ těsném souladu $s$ jeho cíli, obsahem i procesem výuky. Plně se ztotožňujeme s Janem Slavíkem (1999), že „kvalita školního hodnocení spolurozhoduje o celkové kvalitě školní práce“. Ústní zkoušení je vzhledem $\mathrm{k}$ počtu studentů a kapacitám vyučujících nereálné, formou zkoušení je písemný test. Test se vyvíjel společně s celým kurzem a nyní obsahuje uzavřené i otevřené otázky nižší i vyšší kognitivní náročnosti, včetně otázek analytických, kde se posuzuje způsob argumentace. Výrok ze studentského hodnocení: „Požadavky na splnèni predmètu byly jasné a srozumitelné, obsah testu korespondoval s tim, co bylo odprednášeno (oceňuji hodně praktických úkolì, kde byla nutná vlastni argumentace)".

\section{Činnosti ve výuce}

Výuka probíhá formou přednášky, která je prokládaná technikami aktivizace studentů. Snažíme se respektovat psychologické zásady učení, pozornosti a paměti, pracovat $s$ časem na individuální promyšlení kognitivně náročnějších otázek, podporovat metakognitivní strategie a vést výuku tak, aby si studenti např́ pořizovali své vlastní poznámky. Cenný čas kontaktní výuky je věnován především výkladu a aplikaci obtížného nebo velmi důležitého učiva, řešení problémových otázek, informacím, které nejsou v české literatuře $\mathrm{k}$ dispozici, apod.

\section{Činnosti mimo výuku}

Přednášková výuka bohužel není doprovázena semináŕi. Zadáváme proto alespoň dobrovolné úkoly v e-learningu, které nabízejí rozšiřující učivo a podporují zájem studentů. Jsou vnímány oběma stranami jako jednoznačně prínosné, i když je třeba přiznat, že máme opakovaně problémy s jejich včasným ohodnocením. Úkoly jsou vybrány tak, aby doplňovaly obsah nebo rozvíjely určité dovednosti. Například jeden úkol pojednává o pojmových a myšlenkových mapách, které si studenti sami vytvárejí o tématech studovaných v kurzu Obecné didaktiky nebo Pedagogické a školní psychologie. $\mathrm{V}$ minulém semestru ze 179 studentů prezenčního studia tento úkol splnilo $69 \mathrm{z}$ nich. Zajímavá je volba témat: informačně procesni a kognitivní teorie učeni (12), cíle výuky (11), hodnoceni výsledkủ učeni (11), metody výuky (10), motivace (9), pedagogická psychologie (6), žák a školni nelúspěš- 
nost (4), profese učitele a stres (4), školský zákon (2).

Hodnocení studentů: „Určitě oceñuji dobrovolné úkoly $v$ moodlu - byly prínosné a inspirativni (blavnè články v závèru, třeba o formativnim hodnoceni)."

\section{Praktické př́íklady ve výuce}

Využití praktických ukázek ve výuce může být různé, od dílčí výukové situace přes ucelené výukové strategie $\mathrm{v}$ rámci jedné vyučovací hodiny až po komplexní kazuistiky vyučovací hodiny. Ověrily jsme šest různých modifikací využití príkladů praxe: a) trri formy - popis výukové situace, videoukázka, vlastní prožitek ve výuce; b) dvě postavení v rámci výuky - ilustrativní príklad po teoretickém výkladu nebo materiál pro induktivní vyvozování významu nového učiva před výkladem.

\section{ZÁVĚR}

Za hlavní výsledek této studie považujeme následujících šest požadavků na výuku obecné didaktiky $\mathrm{v}$ učitelských studijních programech, které vyplývají z předložené analýzy.

Požadavky na výuku předmětu Obecná didaktika $\mathrm{v}$ učitelském studiu:

1. Obecná didaktika je vstřícná k (budoucímu) učiteli, v centru zájmu je rozvoj didaktického myšlení. Student má být připravován na to, že bude vyučovat, plánovat výuku a $\mathrm{v}$ souvislosti $s$ tím bude činit řadu rozhodnutí, pro která potřebuje srozumitelnou oporu. Výuka didaktiky je orientovaná na stu- denta, nikoli však za cenu podbízivosti a snižování odborných nároků. Primární organizační strukturou obsahu předmětu by neměla být struktura obecné didaktiky jako vědy (byt' sebelépe propracovaná), ale potřeby učitele jako realizátora a tvůrce kurikula. Tomuto požadavku dle našich současných znalostí a zkušeností nejlépe odpovídá koncepce strategického vyučování (strategic teaching, Silver et al., 2007).

2. Obecná didaktika má jasně stanovené cíle. Akcentuje požadavek na posun od deklarativních znalostí studujících směrem $\mathrm{k}$ procedurálním, od jednoduchých myšlenkových operací na úrovni zapamatování směrem ke kognitivně náročnějším úkolům. Atest musí být navázán na cíle, s obojím korespondují učební úlohy a činnosti studujících ve výuce (constructive alignment, Biggs \& Tang, 2011). Písemná zkouška kromě znalostí zjištuje též dovednost studentů aplikovat teoretické koncepty na praktických príkladech nebo analyzovat výukové situace ve světle relevantních teorií, které pomohou dané situaci porozumět.

3. Obecná didaktika je zakotvena $\mathbf{v}$ psychologii učení, v poznatcích o fungování lidského mozku (Škoda \& Doulík, 2011; Ambrose, 2010), vychází též z psychologických potřeb žáka v procesu výuky (Hrabal, Man \& Pavelková, 1989). Východisky obecné didaktiky jsou teoretické základy vyučování a učení (Slavin, 2012; Schunk, 2012) obsahující témata procesů učení žáka, paměti, pozornosti, individuálních zvláštností v po- 
znávání i motivace, vše pokud možno $s$ př́klady aplikací ve školním prostředí. Ve vazbě na didaktickou tradici mohou studenti moderní poznatky kognitivní psychologie napřr vztahovat $\mathrm{k}$ didaktickým zásadám a specifikovat podobnosti a rozdíly. Procesy učení a motivace žáka však musí být základním východiskem pro uvažování o procesu vyučování (Průcha, 2018).

4. Obecná didaktika je zakotvena v empirickém pedagogickém výzkumu, zohledňuje nálezy na důkazech založené praxe a výzkumy v oblasti efektivních výukových strategií (Mareš, 2009; Hattie, 2009, 2012; Marzano, Pickering \& Pollock, 2001; Petty, 2014). Respektuje centrální postavení žáka $\mathrm{v}$ procesu výuky, zároveň není ovlivněna ideologií ani vzdělávací politikou a nezastírá skutečné výsledky výzkumů, je pravdivá. Interpretaci výzkumných dat vede citlivě, $s$ ohledem na typ měřených výsledků a kontext, tj. nikoli např. pouze prezentaci žebrríčků výukových metod. Respektuje jak důležitost př́růstku znalostí žáků, tak podporování jejich autonomie a zájmu o učení.

\section{Obecná didaktika je zakotvena} $\mathbf{v}$ praxi. Teoretické teze je schopna ilustrovat a objasnit na konkrétních príkladech situací z reálné výuky (Silver et al., 2007; Estes et al., 2010; Marzano et al., 2001; Petty, 2014). Obecná vyjádření jsou obdobně nevhodná jako př́klady učení psů či holubů. Pracuje s ukázkovými výukovými situacemi na konkrétním obsahu a např́ić předměty, tj. volí ukázky z prredmětů naukových i výchovných, prrírodovědných i společenskovědných. Optimální je uvádět alespoň dvě rủzné ukázky pro každý důležitý koncept tak, aby nové poznatky nebyly vázány jen na jediný kontext.

6. Obecná didaktika je modelem dobré výuky. Metody výuky vycházejí ze současných požadavků na vysokoškolskou výuku a aktivní učení studentů (Vašutová, 2002; Ramsden, 2003; Biggs \& Tang, 2011), při vědomí nutných omezení daných formátem dvouhodinových přednášek s kapacitou 250 studentů a absencí seminářù. V e-learningovém prostředí nabízí volitelné úkoly $\mathrm{k}$ prohloubení učiva. Přednášky jsou prokládány krátkými aplikačními úkoly, diskusními dvojicemi, hlasováním a dalšími prvky interaktivity, snahou je dodržovat ve výuce princip izomorfismu (Tomková, 2015), resp. kongruentního vyučování (Swennen, Lunenberg \& Korthagen, 2008). Obsah je zároveň i prostředkem: specifikace cílů, efektivní výukové strategie na počátku a na konci hodiny, respektování křivky pozornosti, střídmé používání powerpointu pouze jako podpůrného prostředku vizualizace učiva, aktivizování studentů prostř̌ednictvím kognitivně náročných úkolů a různých forem dialogické výuky, zpětná vazba k plnění cílů, to vše by mělo být standardem každé přednášky.

Domníváme se, že takto koncipovaná výuka obecné didaktiky může dostatečně silně polemizovat s nedávno publikovaným kritickým hlasem S. Štecha: „V minulosti poněkud vyprázdněná ,obecná didaktika' ztrácející 
se bud' v preskriptivní a více ideologické normativitě, nebo $\mathrm{v}$ pohlcení např. obecnou vývojově-kognitivní psychologií, bojuje vlastně o svůj nárok na existenci, o legitimizaci své užitečnosti“ (2018, s. 413).
Za klíčové východisko považujeme vstřícnost ke koncovému prŕíjemci - budoucímu učiteli. Máme na mysli vstřícnost přistupem, obsahem i formou; to vše může podporovat porozumění a společné vnímání účelu a významu obecné didaktiky.

Poděkování: Autorky děkují recenzentovi za kritické připomínky, které vedly k přepracování původně zaslaného textu.

\section{Literatura}

Ambrose, S. A. (2010). How learning works: Seven research-based principles for smart teaching. San Francisco, CA: Jossey-Bass.

Biggs, J., \& Tang, C. (2011). Teaching for quality learning at university: What the student does

(4. vyd.). Maidenhead \& New York: Society for Research into Higher Education \& Open University Press.

Čapek, R. (2015). Moderni didaktika: lexikon výukových a hodnoticích metod. Praha: Grada. Estes, T. H., Mintz, S. L., \& Gunter, M. A. (2010). Instruction: A models approach (6. vyd.). Boston: Pearson.

Hattie, J. (2009). Visible learning: A synthesis of over 800 meta-analyses relating to achievement. New York: Routledge.

Hattie, J. (2012). Visible learning for teachers: Maximizing impact on learning. London: Routledge.

Hrabal, V., Man, F., \& Pavelková, I. (1989). Psychologické otázky motivace ve škole (2. upravené vyd.). Praha: SPN.

Chamoniklasová, J. (2005). Věcný text v české a anglosaské kultuře. In Z. Fišer (Ed.), Tvưrči psaní - klícová kompetence na vysoké škole. Sborník př́spěvků z mezinárodní konference. Brno: Doplněk.

Janík, T. (2003). Didaktika obecná a oborová: pokus o systemizaci pojmů. Brno: Masarakova univerzita, Pedagogická fakulta.

Janík, T. (2009). Obecná didaktika. In J. Průcha (Ed.), Pedagogická encyklopedie (s. 649-652). Praha: Portál.

Kalhous, Z., Obst, O., et al. (2009). Školni didaktika (2. vyd.). Praha: Portál.

Maňák, J. (2003). Nárys didaktiky. Brno: Masarykova univerzita, Pedagogická fakulta.

Mareš, J. (2009). Edukace založená na důkazech: inspirace pro pedagogický výzkum i školní praxi. Pedagogika, 59(3), 232-258.

Marzano, R. J., Pickering, D., \& Pollock, J. E. (2001). Classroom instruction that works: Research-based strategies for increasing student achievement. Alexandria, VA: Association for Supervision and Curriculum Development. 
Pasch, M. (2005). Od vzdělávacího programu k vyučovací hodině (2. vyd.). Praha: Portál.

Petty, G. (2013). Moderni vyučování (6., rozš. a přeprac. vyd.). Praha: Portál.

Petty, G. (2014). Evidence-based teaching: A practical approach (2. vyd.). Oxford: Oxford University Press.

Průcha, J. (2018). Oblasti edukačni reality opomijené českým pedagogickým výzkumem (Online).

Dostupné z www.capv2018.utb.cz

Ramsden, P. (2003). Learning to teach in higher education (2. vyd.). New York: Routledge Falmer.

Schunk, D. H. (2012). Learning theories: An educational perspective (6. vyd.). Boston: Pearson.

Silver, H. F., Strong, R. W., \& Perini, M. J. (2007). The strategic teacher: Selecting the right research-based strategy for every lesson. Alexandria, VA: Association for Supervision and Curriculum Development.

Skalková, J. (1996). Aktuální aspekty rozvíjení didaktického myšlení. Pedagogika, 46(3), 209-213.

Skalková, J. (2007). Obecná didaktika: vyučovaci proces, učivo a jeho výbèr, metody, organizační formy vyučováni. Praha: Grada.

Slavin, R. E. (2012). Educational psychology theory and practice (10. vyd.). New Jersey: Pearson. Slavík, J. (1999). Hodnoceni v současné škole: východiska a nové metody pro praxi. Praha: Portál. Slavík, J. (2009). O teorii pro posthospitační rozbor aneb Reflexe př́běhu výuky jako prostředek rozvoje didaktických znalostí obsahu. In T. Janík et al., Možnosti rozvijeni didaktických znalostí obsahu u budoucich učitelì (s. 33-44). Brno: Paido.

Slavík, J., Janík, T., Najvar, P., \& Knecht, P. (2017). Transdisciplinárni didaktika: o učitelském sdíleni znalosti a zvyšováni kvality výuky napríč obory. Brno: Masarykova univerzita, Pedagogická fakulta.

Starý, K. (2006). Efektivni výnkové strategie. (Disertační práce). Praha: Univerzita Karlova, Pedagogická fakulta.

Swennen, A., Lunenberg, M., \& Korthagen, F. (2008). Preach what you teach! Teacher educators and congruent teaching. (Online). Teachers \& Teaching, 14(5-6), 531-542.

Škoda, J., \& Doulík, P. (2011). Psychodidaktika: metody efektivního a smysluplného učení a vyučováni. Praha: Grada.

Štech, S. (2018). Slavík, J., Knecht, P., Najvar, P., \& Janík, T. (2017). Transdisciplinární didaktika: o učitelském sdílení znalostí a zvyšování kvality výuky napříč obory. (Recenze). Pedagogika, 68(4), 413-418.

Šturma, J. (1993). Didaktické myšlení jako učitelská způsobilost. Pedagogická orientace, 7(3), $57-59$.

Tomková, A. (2015). Princip izomorfismu v učitelské př́ípravě. Pedagogika, 65(1), 75-81.

Vašutová, J. (2002). Strategie výnky ve vysokoškolském vzdělávání. Praha: Univerzita Karlova, Pedagogická fakulta.

Zormanová, L. (2014). Obecná didaktika: pro studium a praxi. Praha: Grada. 
Ing. Karolina Duschinská, Ph.D.

Univerzita Karlova, Pedagogická fakulta, katedra pedagogiky;

e-mail: karolina.duschinska@pedf.cuni.cz

PhDr. Radka High, Ph.D.

Univerzita Karlova, Pedagogická fakulta, katedra psychologie a katedra pedagogiky;

e-mail:radka.high@pedf.cuni.cz

DUSCHINSKÁ, K., HIGH, R. Didactics of General Didactics: From declarative knowledge towards the development of didactic thinking

General didactics has a key position in the study plans of master's degrees in the fields of teaching of general educational subjects, and it is general didactics that we expect to lay the theoretical foundations of the teaching profession. This study has three main goals: to reflect on the educational needs of future teachers, to present a thematic analysis of the most frequently used university textbooks of general didactics, and to analyse the process of innovation of the teaching of general didactics in the light of demands for quality in university teaching. The eight-year process of innovation is illustrated by the interim results of student evaluations of teaching, and the basic aspects of the teaching of the subject of general didactics are analysed: the goals of the subject, content, examination, activity in teaching and apart from teaching and use of examples from practice. The aim of these innovations has been to arrive by progressive steps at a balanced model of the teaching of general didactics, based on the integration of the theory of teaching and the results of empirical educational research with an understanding of concrete didactic situations. The main result of this study is six requirements on the teaching of general didactics in degree courses in teaching.

Keywords: general didactics, the didactics of general didactics, the study of teaching, the development of didactic thought. 